\title{
The bunker and the camp: Inside West Germany's nuclear tomb
}

\author{
Ian Klinke (University of Oxford) \\ Environment and Planning D: Society and Space
}

\begin{abstract}
Recent research has located the camp as the paradigmatic space that emerges when geopolitics and biopolitics intersect. In doing so, it has neglected another space that is indispensable for an understanding of the nexus of these two modalities of power - the nuclear bunker. This paper explores the West German government's now abandoned nuclear bunker in the Ahr valley. Constructed on the site of a subterranean WWII concentration camp, the bunker hosted a number of NATO-exercises, which simulated nuclear war on German soil. Through an analysis of the site's military-strategic context, technical and security features, the paper relates it to its predecessor - the camp - and uncovers a number of spatial overlaps and inversions between the two. Whilst similarly situated within a context of legal exceptionality, hygiene, logistics and total war, the concentrated living space of the nuclear bunker turned the camp's logic of extermination inside out. The nuclear bunker was a concrete crypt in which sovereign power and total war sought to find eternal peace.
\end{abstract}

\section{Introduction ${ }^{1}$}

Debates on the intersection of geopolitics and biopolitics have become formative to Political Geography over the last decade. This literature has tended to explore the camp as the iconic space that emerges at the junction of political life and political earth, forming both an overpowering political order and a network of concrete material spaces. The vast majority of this work has addressed the return of the camp during the Global War on Terror and the subsequent US-led occupation of Iraq (Diken and Lautsen, 2006; Gregory, 2006; 2007; Minca, 2005; 2006). Others have investigated the Nazi Germany's struggle for a racially purified Eastern living space (Giaccaria and Minca, 2011: 11), the emergence of the camp in NATO's 1999 war against Serbia (Edkins, 2000), the everyday geopolitics of refugee camps in the Israeli-Arab conflict (Ramadan, 2009; 2013) or camp-like logics in contemporary border regimes (Vaughan-Williams, 2009; van Houtum, 2010). In doing so, this growing literature has so far tiptoed around the period of the Cold War.

In other realms of Political Geography, the study of the Cold War has acted as a hub for conceptual innovation, particularly by giving birth to critical geopolitics in the early 1990s. Whilst the focus here was initially on the discourses of policy-makers and strategists (Dalby, 1990; Ó Tuathail and Agnew, 1992), subsequent work examined how the Cold War was fought in the realm of popular geopolitics (Sharp, 20oo; Dodds, 2003). More recently, researchers have suggested ways in which the Cold War can be

\footnotetext{
${ }^{1}$ I would like to thank Ulrich Best, Luke Bennett, Bradley L. Garrett, Craig Jeffrey, Chris Hendershot, Tom Jellis, Judy Pallot, Richard Powell and Anna Toropova for comments and suggestions on spoken and written versions of the paper. I am especially grateful for conversations with Jörg Diester at the Dokumentationsstätte Regierungsbunker in the initial stages of the project.
} 
studied in self-reflective, micro-sociological and more than textual ways (MacDonald, 2006b; 2008; Matless, Oldfield and Swain, 2008), paying attention in particular to abandoned military landscapes, including bunkers (Bennett, 2011a; 2011b; Woodward, 2013: 46). Whilst Geographers have long argued that Cold War geopolitics emerged smoothly from fascist and imperialist mappings (Ó Tuathail, 1996: 87; MacDonald, 2006a), the question of Cold War biopolitics is yet to be explored and placed in its historical context.

This paper makes a tentative step in this direction, refocusing the question of geo- and biopolitics from the camp onto what is perhaps the most defining of Cold War spaces - the nuclear bunker. By examining a governmental nuclear bunker that emerged on the very site of an underground concentration camp, the Federal Republic of Germany's governmental bunker in Marienthal, it unearths forces that managed to survive the scorched earth, ruined cities and crematoria of the fascist living space. In an attempt to unpack the spatial politics of the governmental nuclear bunker, the paper interrogates its design, technological functions and materiality as well as the policy and media debates surrounding it. It draws especially on declassified ministerial material found in the Federal Archives in Koblenz and secret service files at the Federal Commissioner for the Stasi Archives in Berlin. ${ }^{2}$ Finally, the research is informed by a number of visits to the bunker, which were used to collect photographic evidence. By exploring this subterranean space as a materialisation of geopolitics, it finds inspiration in recent literature that has explored the 3-dimensionality of geopolitics (Elden, 2013; Graham, 2004; Weizman, 2007) and contributes to work that has reintroduced materiality into the critical study of international politics (Barry, 2013; Dittmer, 2013).

The paper starts by sketching the uncanny story of a disused railway tunnel that turned into a slave labour camp only to be reborn as the West German governmental nuclear bunker. Subsequently, the article presents a structured reading of the literature on the geo- and biopolitics of the camp and brings it into dialogue with Paul Virilio's theorisation of the bunker. It then draws on this discussion in an attempt to dissect Marienthal's cryptic concrete, finding a number of disturbing overlaps and inversions with the archetype of the camp. Focusing in particular on logistics and legal exceptionality, hygiene and total war as well as the question of living space, it argues that the bunker's drive to protect its concentrated interior from the nuclear holocaust outside turns the camp's logic of extermination inside out. Moreover, the governmental nuclear bunker stretches the paradigm of immunisation, identified by Esposito (2008) as the heart of modern biopolitics, to its thanatopolitical vanishing point - the destruction of humanity.

\section{From camp to bunker I}

Roughly 16 miles south of the former West German capital of Bonn, lies the West German government's now abandoned nuclear bunker. Surrounded by vineyards, forests and half-timbered houses, this remarkable subterranean structure was moulded into the earth by three World Wars. The story began in 1913, when a number of railway tunnels were dug along the river Ahr in preparation for a surprise attack on France. The railway was not finalised in time for WWI however and the infamous Schlieffen plan had to be executed without one of its supply lines. After the war, the site lay abandoned and slowly lost its strategic importance due to technological advances in

${ }^{2}$ All translations from German into English are the author's, as are images 3-8. 
the field of mechanised warfare and aviation. In 1936, after the National-Socialists had taken power in Germany, the tunnels were briefly used to grow mushrooms, which like the wine that ripened on the valley's slopes, was meant to rival superior French production (Janta, Rieck and Riemenschneider, 1989: 140). When during WWII the German industrial centres became the target of heavy aerial bombing, production was often moved underground and in 1943 the railway tunnels on the river Ahr were turned into a small subterranean slave labour camp of around 200 inmates.

Whilst photographs of the camp show the archetypical barracks located in front of the reinforced railway tunnels (image 1), the camp's remains were unmarked after 1945, known only to the survivors and the local population. It first came into the public eye in the mid-1980s when an investigative journalist started exploring what he believed to be the West German government's wartime retreat and stumbled on stories of a WWII concentration camp (Preute, 1984). Poetically named Rebstock (grapevine), this subcamp of the notorious Buchenwald concentration camp was a production site for the Third Reich's cruise missile $\left(V_{1}\right)$ and the ground vehicles for the world's first ballistic missile (the V2). The camp was subject to a continuous influx and outflow of inmates as those deemed unfit to work were sent back to Buchenwald (Jungbluth, 2000: 61). Towards the end of the war, Rebstock had become the target of British bombing campaigns. During the winter of 1944/45, the local population sought refuge in the tunnel and production was brought to a halt. It was in those days that the civilian population came into close contact with the camp inmates, as local residents have testified since (Gückelhorn, 2002: 65), thus blurring the boundary between the camp's inside and outside.

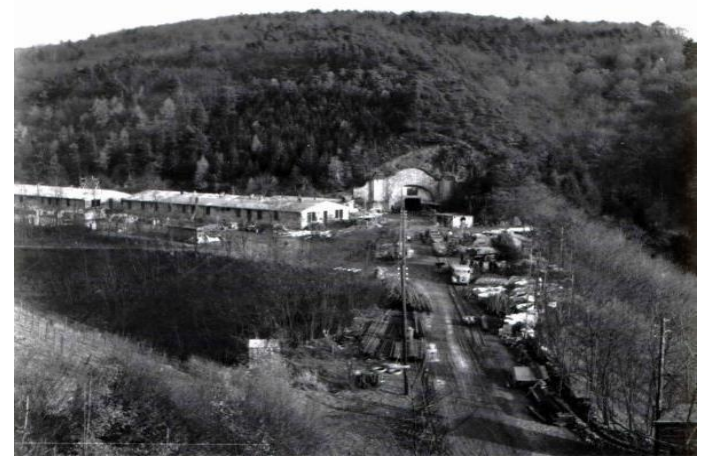

Image 1 camp 'Rebstock' (1944)

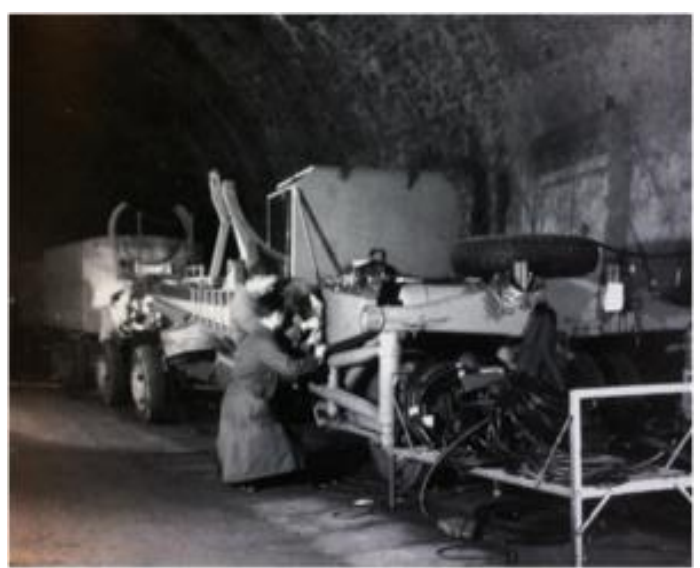

Image 2 assembly of V2 ground vehicles (1944)

In 1945 the allies destroyed the reinforced entrances with targeted explosions, as if to disallow geo- and biopolitics to return to this particular space (Bundesinnenminsterium, 1959a). Nevertheless, in the 1950s, the site became the target of the government's preparations for the next war, a nuclear war that threatened to be fought out on German soil. It was in this context that sovereign power returned to a valley whose inhabitants were already schooled in keeping subterranean secrets. Thus, the West German state made a bold investment and turned the reinforced tunnels into a small underground city. Constructed from 1960 to 1972, this emergency seat (original codename 'rose garden') could host up to 3,0oo politicians, bureaucrats and military staff for one month into a nuclear war. Although it was deemed unsafe by 
engineers on a number of occasions (Bauamt Bonn der Bundesbaudirektion Berlin, 1961; Bundesinnenministerium, 1969), the project was not abandoned and from 1966 onwards, became the home of a number of semi-secret NATO-exercises. As East German intelligence shows, these exercises controversially included not just the simulation of pre-emptive nuclear strikes on the Warsaw Pact but also on West German cities that had been taken by the advancing Soviet army shortly before (Ministerium für Staatssicherheit, 1966). The bunker was in operation until its eventual decommissioning in 1997, briefly halted only after September 11, 2001. Since 2008 a small part of the bunker has served as a heritage site.

It is important to note that there are a number of sinister connections between the nuclear bunker and the camp other than just the shared location. Firstly, the bunker at Marienthal was run by a number of men with a CV in total war. Most prominently, this included Theodor Busse, commander of the 9th army and General Walther Wenck, commander of the $12^{\text {th }}$ army, who were both involved to the last minute in Hitler's self-destructive Battle for Berlin. The bunker's chief of security was former SS Hauptsturmführer Theo Savaecke, also known as the 'butcher of Milano' and convicted in 1999 for war crimes (Breitman et al, 2005: 169). Secondly, the bunker's construction consortium comprised a number of companies that had been involved in the construction of the Third Reich's network of camps and bunkers (Bundesinnenministerium, 1965). Holzmann AG, for instance, was involved both in the construction of the Atlantic Wall as well as in that of the Monowitz slave labour camp, also known as Auschwitz III (Pohl, 1999: 261). Hochtief AG, used slave labour for a whole range of major projects during Hitler's twelve year Reich, which included not just the the Westwall (Siegfried line) of defensive fortifications and tank traps, but also the two most iconic of the Third Reich's bunkers, the Wolfsschanze headquarters in Rastenburg (Ketrzyn) and Hitler's tomb, the Führerbunker in Berlin (Hochtief, 2014). 3 The most controversial member of the consortium, as noted already by Diester (2009, 130), was the Huta AG. Bankrupt in 1985, Huta AG is also known to have built the crematoria at Auschwitz-Birkenau. Although they hold little explanatory power, the above continuities hint unsubtly at the intimate connection between the camp and the bunker. Whilst these two exceptional spaces emerged in the same place, they also stood at the same nexus of bio- and geopolitics. To understand how the nuclear bunker both reproduced and folded the camp inside out, the following section will unpack these two spaces in a more theoretical register.

\section{From camp to bunker II}

Fuelled primarily by its prominent role in theorising the global war on terror, biopolitics has now established itself as an important focal point for debates across Human Geography and has inspired scholarship on topics as diverse as migration, HIV, airports, climate change and food provision. Although the wide array of competing conceptualisations of biopolitics has led some observers to suggest that the signifier 'has gone a bit wild' (Rutherford and Rutherford, 2013: 412), the majority of Geographers has tended to approach biopolitics through the theories of Michel Foucault and Giorgio Agamben. In the late 1970s Foucault began to trace the ways in which life itself had increasingly become the object of modern governmental practices and argued that sovereignty's old right over life and death had increasingly given way

\footnotetext{
3 Of course, the governmental nuclear bunker at Marienthal in many ways resembles the Führerbunker in Berlin. Yet, it was particularly the advance of nuclear war and its logic of extermination that highlights its connection to the camp as the thanatopolitical underside of biopolitics.
} 
to a new power, a power of fostering life (Foucault, 1976; 1978). Even nuclear war, he held, was fought not in the name of the sovereign but the preservation of the population's life - paradoxically to the point of risking its very death (Foucault, 1976: 253).

Agamben builds on these pioneering insights but departs from Foucault by refocusing biopolitics on the question of sovereignty and the law. Zooming in on the simultaneously legal and extra-legal logic of the state of exception, he argues that sovereign power constitutes itself and its counterpart, 'bare life', in and through exceptional spaces. In a now widely familiar argument, Agamben traces this production of bare life back to a distinction in Ancient Greek between political (bios) and natural life (zoe). He claims that biopolitics functions as the calculation, government and abandonment of zoe, though in ways that ultimately include it through its very exclusion. He finds this rendering of bare life again in the Roman legal figure of homo sacer, an expellee from the community who cannot be meaningfully sacrificed and can therefore be killed with impunity (Agamben, 1998: 102). Homo sacer, therefore, is human existence that has been deprived of its rights and its political voice - life that is exposed to death. Through a process of progressive normalisation, Agamben argues, states of exception have a tendency to turn democracies into dictatorships and render their citizens potential hominess sacri (111). He holds that these logics were most visible in the Third Reich's rule of emergency decrees and more specifically in the tightly sealed and hygienic space of the concentration camp. As Minca (2005: 407) following Agamben puts it, sovereign power requires the camp as 'a material and mappable space within which violence becomes the constitutive element of both the torturer and the victim'. Like others before him (Bauman, 1989), Agamben suggests that the deadly underside of biopolitics (thanatopolitcs) as materialised in Auschwitz was not so much a flaw in the project of modernity as its constitutive and repressed underside. The camp, in other words, was and remains today the hidden paradigm of Western modernity (Agamben, 1998: 181).

This politically pessimistic reading of Western modernity has not been without its critics. Ernesto Laclau has accused Agamben of a 'naïve teleologism' that fails to see the messiness of modern biopolitics and precludes the emergence of modernity's emancipatory potential (Laclau, 2007: 22). Pushing this critique further, Mark Mazower has questioned whether Auschwitz should be read as the symbol of the genocidal episode of the WWII. He points especially to the death of 2.1 million Soviet soldiers in German POW camps during 1941/42 that occurred as part of a logistic failure rather than the bureaucratic and medicalising logic of biopolitics foregrounded by Agamben (Mazower, 2008: 31). This latter point highlights an important omission in Agamben's original theorisation of biopolitics, the question of geopolitics, military logistics and the embeddedness of the Holocaust in a wider landscape of total war. This is particularly surprising given that the term 'biopolitics' originates in the thought of a famous geopolitician, Rudolf Kjellén (1920: 94).

Highlighting the spatial relationship between the bio and the geo, Giaccaria and Minca argue that the Nazi camps were intimately linked to the fantasy of an Eastern empire. 'The "shrinking" of the internal spaces of the camp', they hold, 'was a functional and symbolic counter-dimension to the expansive nature of German lebensraum' (Giaccaria and Minca, 2011: 5). The vast and open living space, in other words, relied on the cramped and concentrated space of the camp as a means of racial 'purification'. This dependence, however, was not simply reproduced during the Cold War. Whilst its many military conflicts, from Korea to Afghanistan, involved POW camps, the Cold War did not simply see the death camp or the fantasy of lebensraum 
re-emerge. Unless one assumes the camp as a mere metaphor for the politics of modernity, it is difficult to read the camp as the defining space of that era. Yet, if we look closely at what was arguably the most iconic of Cold War spaces, a stealthy morphing and inverting, a moving underground and a pouring into concrete of the fascist spatial logic comes into vision.

Although the subterranean survival capsule of the bunker has its origin in the context of WWI trench warfare, the modern bunker was born out of the technological possibility (poured concrete) and political will to take out whole cities (the aerial bombing campaigns of WWII). Bunkers emerged in the same political context as the death camp, chosen by Agamben as a symbol for modernity's underside - total war (or at least the threat of total war). Like the camp, the bunker is often read as a modern excess, 'the waste of modernity that cannot be tidied away' (Beck, 2011: 83). Similar to the 'anxious urbanism' of Cold War era urban planning (Farish, 2004: 94), nuclear bunkers materialised both the fear of nuclear war and a radical disillusionment with urban life. Like camps, they functioned as 'anti-cities' (Virilio and Lothringer, 1983: 132), although in practice the two iconic spaces have often complemented one another in an age of asymmetric warfare and growing urban inequality (Duffield, 2011: 768; Weizman, 2007: 66; 256).

Crucial to any understanding of the bunker's spatial politics is the work of Paul Virilio and his conception of the bunker as a spectacular, cryptic and insecure monolith. Captivated by the aesthetics of Hitler's Atlantic wall, his seminal Bunker Archaeology (1975) approaches bunkers as monolithic spaces that promise survival in an era of aerial bombing, asphyxiating gases, flamethrowers and nuclear warheads. They emerge in an age in which weapons have become so omnipotent that distance can no longer act protectively. Interested in the politics of oblique angles and the influence of poured architecture on $\operatorname{mid}-2 \mathrm{O}^{\text {th }}$ century architectural styles like Brutalism, he discusses the bunker as a paradoxically secure and insecure space. Although the Atlantic wall was the harbinger of a new age of total war (1975: 45), he also reads it as a symbol of weakness and imperial overstretch, a strategic still birth. The bunker is always theatrical, built for a gaze from which it would seem impenetrable (47). In this sense, the bunker often has a psychological rather than a strategic value, it establishes identity where this very identity is under threat. ${ }^{4}$ Reflecting on German air-shelters that were converted into churches, he holds that 'these places of shelter from danger, and places of worship, [] are also places of salvation' (Virilio, in Armitage, 2009: 23). Like stone chambers beneath Christian churches, he argues, bunkers have functioned as underground places of security, hidden and forbidden places, 'as in the English word, cryptic' (ibid). It is specifically the subterranean celebration of death in the crypt that links the nuclear bunker to the thanatopolitical space of the camp. Other scholars have alluded to the bunker's 'womb' and 'tomb' like properties (Beck, 2011: 82) or its dual role as 'shelter' and 'grave' (Bennett, 2011a: 156) to capture this ambivalence.

In a 2006 foreword to Virilio's Speed and Politics, Benjamin Bratton briefly stages an encounter between Virilio's writings on the bunker and Agamben's reading of the camp to argue that both spaces should be understood as doubles. He notes that

\footnotetext{
4 Whilst Virilio's prolific writings have inspired generations of thinkers, they have to be approached with the necessary critical distance for they are themselves caught up both in the geopolitical gaze (Luke and Ó Tuathail, 2000: 364) and bunkered thought (Gane, 1999: 100). Moreover, Virilio's insistence that bunkers are monolithic clearly has its limitations when different layers of geopolitical sedimentation in the biographies of specific bunkers are taken into consideration (Hirst, 2005: 213).
} 
both are 'hygienic' and 'defensive' but whereas bunkered space functions as 'a concrete prophylactic, the camp is incarcerating' (Bratton, 2006: 19). Indeed, both spaces attempt a radical inside/outside distinction. Whilst one is an architectural membrane against a hostile world', the other performs 'an expulsion-by-enclosure of the Other from the normal performance of law' (ibid). Indeed, it can be argued that the nuclear bunker turns the biopolitical logic of the camp inside out. Whereas the Nazi empire's Eastern living space was punctuated by concentration and death camps, the subterranean living spaces of the nuclear bunker would be scattered across a potential landscape of Cold War extermination. Like Virilio, Bratton goes on to emphasise the role of logistics as the fundamental socio-technical condition of possibility for both spaces, 'where the only compulsion is the execution of governance on a raw mass, mobilising it, diagramming it' (ibid).

Any exploration of the similarities and dissimilarities between the nuclear bunker and the concentration camp will have to start by noting the obvious, namely that the Cold War, unlike WWII, did not fully unleash its logic of extermination. Bratton is right to identify the logistics of governance as being at the heart of the two spaces but his insistence that they are 'often architecturally identical' is more questionable. After all, it is difficult to see how the nuclear bunker's reinforced concrete would resemble the notorious huts, fences, watchtowers and crematoria of Auschwitz. Moreover, it seems problematic to treat the nuclear bunker as a passive and static space, as Virilio does since the bunker too is a place from which the Other is expelled. As will be illustrated below, the sovereign decision over life and death became very much localised and materialised in the West German nuclear crypt itself. In what remains, I would like to argue that the protective space of the nuclear bunker overlaps and inverts the lethal space of the camp.

\section{Overlaps}

Like Rebstock and other concentration camps, the nuclear bunker at Marienthal was a tightly sealed and hygienic living space that existed both within a network of modern logistics and a landscape of total war. It pre-emptively materialised the state of exception, thus playfully blurring the boundary between democracy and authoritarianism. Crucially, it was a space of insecurity in which the boundary between the bunker's inside and outside was fundamentally blurred. Yet, the nuclear bunker was also characterised by a different temporality, another telos, a distinct final solution and it is here that we can begin to understand the way in which the nuclear bunker stretches biopolitics to its vanishing point.

Most importantly, the bunker was subject to high concentrations of sovereign power, crystallising in an exceptional geography and the exposure of life to death. The latter is particularly visible in a string of NATO exercises that were performed in the bunker between 1966 and 1989. All of these simulations operated with similar storylines, typically starting with instability in the East block. This geopolitical volatility would lead to superpower tensions and a deployment of Soviet troops at the German-German border, followed by a Soviet attack. After a period of conventional warfare and the use of chemical weapons by the Soviet Union, NATO would respond with pre-emptive nuclear strikes in an attempt to force the Red Army to retreat. These exercises simulated the transition into a state of emergency and the decision to deploy nuclear weapons and sometimes the entry into all out nuclear war. As East German intelligence shows, the 1966 exercise "Fallex 66" included the nuking of West German cities and villages that had been taken by the advancing Soviet army only hours before 
in an attempt to create a $50 \mathrm{~km}$ impenetrable cordon of destruction, from Göttingen via Hünfeld (near Fulda) to Eslarn on the Czech border (Ministerium für Staatssicherheit, 1966). West Germany and other member states had the right to consult the United States in its sovereign decision over the use of nuclear weapons. Given however that Germany itself was to serve as the battlefield of this war, this privilege only highlighted its lack of sovereign control over its own territory and population. However, even during the 1980s, simulations still necessitated the West German placebo sovereign to use military violence against its own population, especially against peace protestors and strikers (Der Spiegel, 1985: 15).

Whilst Geographers have stressed the topological and unlocalisable nature of the state of exception (Belcher et al., 2008), it is important to note that there are spaces like the nuclear bunker in which the state of exception materialises unambiguously. In the West German case this was through the enactment of the controversial 1968 Emergency Acts (Notstandsgesetzgebung), which ensured the government's ability to act in an emergency such as a nuclear war. These laws, briefly mentioned by Agamben (2005: 11), allowed the young West German liberal democracy to strengthen its executive and effectively morph into a semi-authoritarian state during a state of exception, similar to the Bush administration's emergency decrees after 9/11. To be precise however, the bunker was not so much a space that emerged through emergency decrees, like Guantanamo Bay, but rather a space in which these decrees were playfully enacted (even before they were passed in the Parliament). Like the camp, the site operated in a strange limbo between secrecy and transparency, securitised exception and liberal norm. Whilst it was hidden from the public eye and obscured within the federal budget (Bundesinnenministerium, 1973), information about the bunker was frequently leaked to the press. Although it was not strictly speaking an extra legal space, the question of ownership was at least ambiguous; the national rail company still owned the tunnels whilst winemakers still owned the slopes above the bunker. Interestingly, the ministry dismissed the problem of ownership by referring to the WWII labour camp in Marienthal. In a 1960 letter to the Ministry of Transport, the Ministry of the Interior brushed away objections by noting that a similar solution had already been established during 1944, going on to add that the Chancellery had ordered that the matter should be pushed forward 'without any bureaucratic inhibitions' (Bundesinnenministerium, 1960).

Marienthal protected its occupants from a range of threats, including a nuclear blast wave, radioactive fallout as well as biological and chemical agents. Like the camp, it was a site of advanced logistics, both in its peacetime organisation and in the planning for life during nuclear war. In order to function as a tightly sealed and autarkic space, the structure relied on a whole range of technologies, such as blast doors, reinforced concrete, $\mathrm{CO}$ alarm systems, radiometers, $\mathrm{ABC}$ filters and decontamination facilities. At the same time, the bunker had to provide the supply of oxygen, food, power as well as discharging waste in order to make human survival possible inside the hermetically sealed capsule. In order to increase its resilience, the bunker was divided into two segments that could survive independently. Furthermore, the bunker included offices, hospitals, a dentist, a church, a cinema and a hairdresser to maintain the physical and spiritual wellbeing of its occupants. Life in the bunker was planned to the last detail, from meetings and meals to hairdresser appointments. Water was rationed and the calculation of personal and office space was calculated depending on rank and entry into the different parts of the building was tightly regulated by different identification cards (Der Spiegel, 1984: 73). 
This logistic apparatus, which aimed to ensure a hermetically sealed space, resembled that enabling the camp. As Giaccara and Minca (2011: 5) have argued:

'The rigid separation between the camp and its exterior was paralleled by an obsessive calculative management of the interior. The internal spatialities of the camp - from the dormitories to the latrines - were planned in detail in order to minimize the consumption and the use of space, and to maximise control and discipline' (Giaccaria and Minca, 2011a: $5)$.

In this way, ministerial files from the 1960s and 1970s reveal little tables with human labour and partitioned space, technical jargon, long lists of resources and components as well as complaints about shortages and about a lack of secrecy. What is particularly striking about these calculations is an obsession with cleanliness, even the cleaning of offices was carefully calculated (Bundesbaudirektion, 1968a). Moreover, the question of hygiene also surfaced in relation to the toilets and the sewage system. Already in 1959 ministerial records noted that local communities had already suffered from unpleasant odours when sewage from what was then the camp was discharged into the local river during WWII (Bundesinnenministerium, 1959b). The issue emerged again during the site's construction and in 1967, a year after the government had paid an unnamed 'institute of hygiene' to test the sewage plant (Bundesinnenministerium, 1966), the site's sewage had turned into what the local administration called a 'political issue' (Stadtverwaltung Ahrweiler, 1967). It is interesting to note that it was not the bunker's elitist and exclusive logic or the political insensitivity of constructing it on a former concentration camp that caused an outrage but the bunker's lack of hygiene. In response to this pressure, the treasury decided to build what it called a 'federal sewer' (bundeseigener Abwasserkanal), an exceptional tunnel that bypassed the local population's sewage system, highlighting the privileged position of the sovereign's bunker (Bundesschatzministerium, 1967).

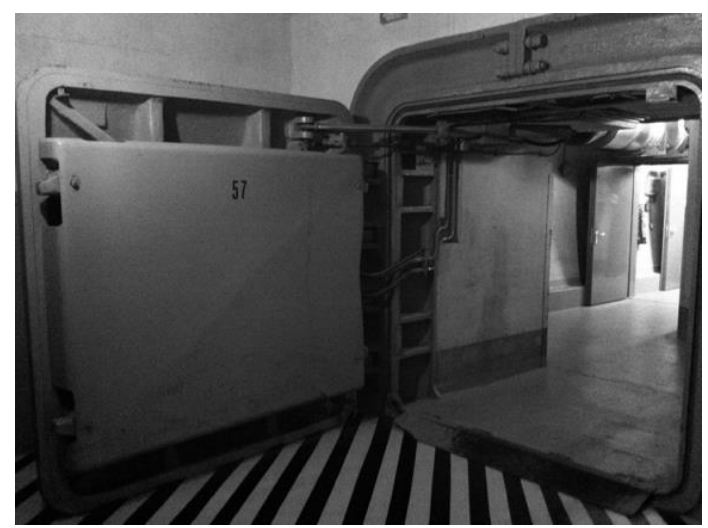

Image 3 blast door (2013)

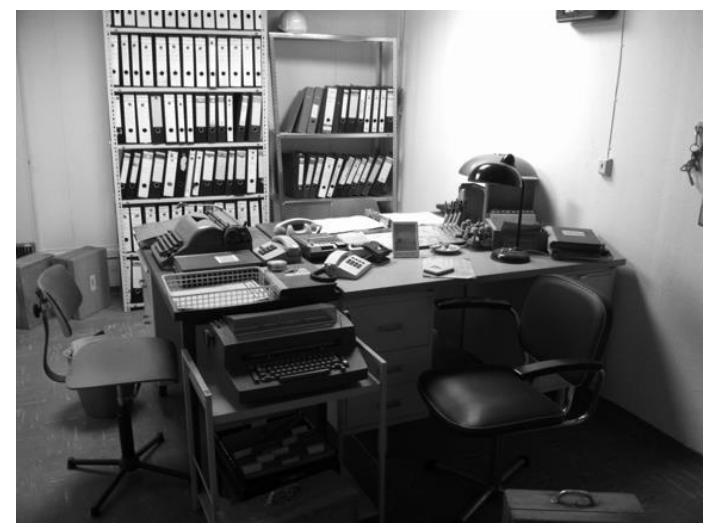

Image 4 office (2013)

\section{Inversions}

Whereas the previous section has shown that in many ways the nuclear bunker at Marienthal resembled the archetype of the camp, this section argues that in crucial ways it folded the camp inside out. This becomes particularly apparent when the bunker is read through the simultaneously geo- and biopolitical notion of lebensraum (living space). The German term raum translates into English both as 'space' and 
'room' and therefore captures open as well as confined spaces, both the Nazi plans for a vast peasant empire and the cramped space of the nuclear bunker. As has been noted above, they were logistic and hygienic spaces, both of which also functioned as powerful fantasies for the state elites and wider populace. In other respects, the two living spaces are hardly congruous. In fact, the nuclear bunker in Marienthal directly contradicted Friedrich Ratzel's influential formulation of lebensraum that had stressed the importance of open space. In a famous 1901 essay he claimed that 'vast spaces are life-sustaining' (Ratzel, 1901: 169) but warned that the 'struggle for life' [Kampf ums Dasein] became 'desperate in narrow spaces' (153). The dissonance between fascist and Cold War geopolitics is most clearly understood as a spatial inversion of life and death. The nuclear bunker was devised to protect its concentrated living space inside from the holocaust outside whilst Nazi living space was racially 'purified' through the genocidal logic of the camps. This inversion is especially visible in Marienthal's decontamination facilities and its watchtowers.

As the building authorities ordered, the bunker's main exists had to include decontamination facilities (image 5), which could be bypassed in normal cases, but which had to be passed in a state of emergency [Katastrophenfall]. It went on to detail a procedure whereby a contaminated person's hands and feet were examined by a radiometer after which their clothes were thrown into a chute and the body was showered in citric acid (Bauamt Bonn der Bundesbaudirektion Berlin, 1961). A month later, the Ministry of the Interior cautioned in unmistakably biopolitical tones that individuals would need to be subjected to sophisticated tests in order to see whether radioactive materials had entered beyond the clothing and into the body. The document emphasised that this was 'important both for the person affected and for the surroundings' (Bundesinnenministerium, 1961). This would suggest that such a highly contaminated person might not be permitted to re-enter the bunker and would thereby be rendered bare life, life exposed to death. It is perhaps hardly coincidental that these decontamination showers function to invert those in Nazi extermination camps. Like at Auschwitz, these showers were integrated into a biopolitical machine that medicalised the human body and claimed to 'decontaminate' or 'delouse' it. It is here that a sovereign decision would be taken on whether an individual was let inside the bunker or left outside to die. Interestingly, in 1968 scientists ran a number of tests with the bunker's filter system. One of the test substances was hydrogen cyanide, also used in the gas chambers under the name 'Cyclone B' (Bundesbaudirektion, 1968c).

Although officially run by the Bundesamt für zivilen Bevölkerungsschutz (the Federal Office for Civil Defence), the structure was in fact only designed to accommodate the bureaucratic elites. Underneath a façade of care for life (bevölkerungsschutz translates literally as 'the protection of the population') was a sovereign space devoid of its population. This dynamic can be found in the watchtowers (image 6), which were added to the structure in the 1980s. In January 1968, the Federal Building Office first asked for such fortifications to be built, demanding protection from conventional warfare and noting in particular the threat from demolition bombs, missiles and artillery projectiles (Bundesbaudirektion, 1968b). This happened notably at the height of the West German student protest movement and only months before the controversial emergency laws were passed in the West German Parliament. It is therefore worth asking whom these fortifications were directed against. After all, the watchtowers would hardly have withheld the advancing Soviet army and would, if at all, have drawn unnecessary attention to the bunker. ${ }^{5}$

\footnotetext{
${ }_{5}$ Moreover, the Red Army Fraction (Baader Meinhof group) can be ruled out, too. Although the members were already politically active in 1968, the terrorist cell was founded only two years later.
} 
Given that the NATO simulations required the stamping out of various forms of public unrest, it is more than probable that these fortifications were built to prevent the German population's entry into the bunker. Whereas the concentration camp watchtower prevented those on the camp's inside from escaping and 'contaminating' the lebensraum, the watchtowers in Marienthal prevented the German population outside from getting access to the hygienic living space of the bunker.

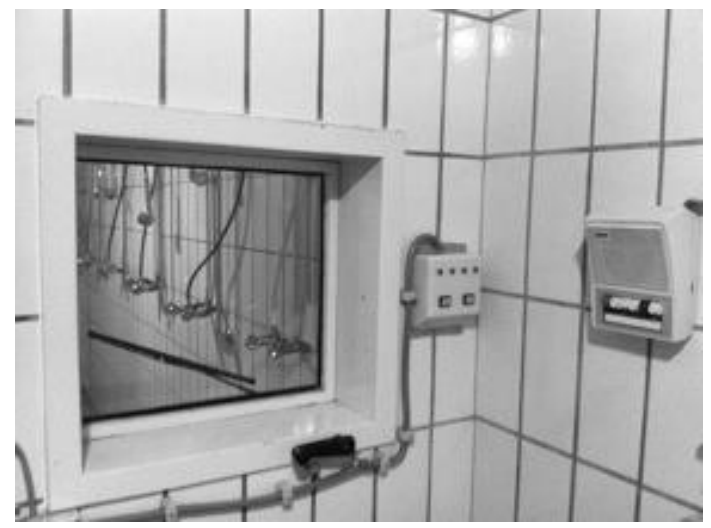

Image 5 decontamination showers (2013)

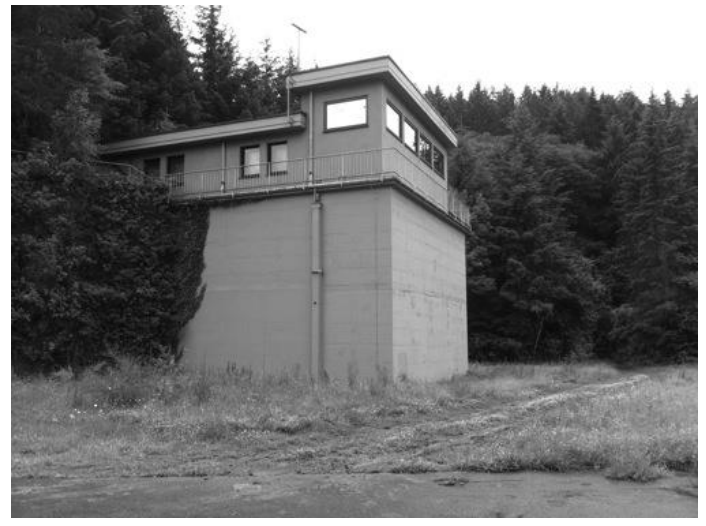

Image 5 entrance and watchtower (2013)

These inversions begin to challenge the idea that the nuclear bunker merely functioned as yet another version of the camp. Moreover, the nuclear bunker stretches Esposito's concept of immunisation to its limit. For Esposito, immunisation is the process at the heart of biopolitics by which the production of death functions as the cure in the preservation of life. The way in which the Nazi state turned this biopolitical apparatus against its own body (volkskörper) is powerfully symbolised by Hitler's suicide in the Führerbunker (Esposito, 2008: 10). The simulated killing of West German cities during the NATO exercises similarly displays the logic of immunization. By risking the end of life on earth for the preservation of an abstract idea of a life worthy of living, thermonuclear war exceeded the logic of the camp. Given the assurance of mutual destruction, the effects of nuclear war were in a sense 'no longer simply genocidal' but threatened the very survival of life on earth (Shaw, 2004: 143). In this way, the bunker revealed itself as a space of pure sovereign power that was devoid of the original object of biopolitics, the population. Although the bunker appeared on paper as a civil defence measure, the population's protection was in fact no more than a fig leaf for the shelter of naked sovereign power, its bureaucratic staff, its typewriters and its filing cabinets. Whilst it was meant to assure the sovereign's survival through a limited nuclear war, its very existence increased the chances that such a war might spiral into a full-scale thermonuclear war.

In this sense, the nuclear bunker in Marienthal was an obsessive raum ohne volk (space without people) that inverted the interwar fixation with its opposite - volk ohne raum. It was a thanatophilic space, resembling in its relationship with time and endings less the camp than the grand architectural designs of Nazi Germany. Albert Speer, Hitler's architect and Minister of Armaments and War Production famously designed buildings that would ruin beautifully in centuries to come, terming this morbid approach his 'theory of ruin value' (Speer, 1970: 97). By constructing the present as past in the future and playing with an aesthetics of 'disappearance' (Virilio, 1975: 57; Vanderbilt, 2002: 128), nuclear bunkers functioned within the same temporal economy as the fascist architectural landscape. However, it was not so much the bunker itself that was to turn into ruin and rubble than its outside. Like the Nazi architectural landscape that was supposed to produce beautiful ruins in a 1000 years' 
time, the nuclear bunker imagined its demise from a position in which the world was in ruins (a truly final solution). Ironically, in the case of a nuclear war, the long-range ballistic missile that had once been manufactured at camp Rebstock with the use of slave labour would have returned to haunt the bunker, creating not a racially purified living space but a wintery landscape of extermination. ${ }^{6}$ If the camp had once functioned as the space where sovereign power was re-produced, then the nuclear bunker would have served as its tomb.

\section{Conclusion}

This investigation of the West German government's emergency seat has sought to shed new light on the intersection of $20^{\text {th }}$ century geopolitics and biopolitics. It has told the story of a nuclear bunker that was built to protect lives in a geopolitical conflict that threatened to rid the earth of life itself. In many ways, the nuclear bunker tended to replicate the spatial logic of the camp, that iconic architectural space standing at the vanishing point of Nazi geo- and biopolitics. Like the camp, the nuclear bunker was an ultimate space of exception within which extermination was rendered possible and even rational. It was enabled and governed by a highly concentrated form of sovereign power, by a logistic apparatus that was obsessively committed to the creation of hermetically sealed and hygienic living space. Yet, despite these congruities, this paper has argued that the nuclear bunker should also be read as a geo- and biopolitical space in its own right. A number of important inversions between the two spaces highlight this point. Most importantly, the nuclear bunker was designed for a different telos than the camp; its final solution was a tightly sealed sarcophagus for sovereign power, preserving it into the nuclear darkness and stretching the logic of immunisation to its vanishing point.

It is architecture's destruction rather than its construction that has more commonly figured in debates on geopolitics (Fregonese, 2012). More often than not, it has been interpreted as a passive expression of geopolitical transformations rather than an active shaper of geopolitical discourse. The nuclear bunker, in many ways, was such an active agent. In the case at hand it both enabled the Cold War's ritual performance through the NATO simulations as well as a range of resistances. In 1971, for instance, the local mayor in nearby Dernau threatened the state with a protest of local winemakers (Gemeindeverwaltung Dernau, 1971). It was not the issue of nuclear war that was at stake, but rather the legally ambiguous and materially active space of the bunker, which was producing a whole range of problems for the winemakers, from surface collapses and bad harvest to the aforementioned sewage problems. Perhaps more influentially, the 1968 student protest movement emerged at least partially in response to events relating to the bunker. When the Emergency Acts were first enacted in the bunker during the NATO exercise Fallex 66, unrest was sparked in the population and lead to the grand coalition under the Conservative (and former Nazi) Chancellor Kurt Kiesinger being nicknamed the 'bunker coalition' in East Germany (Die Zeit, 1966). This highlighted the bunker's theatrical and spectacular dimension, its 'concrete ambivalence' (Beck, 2011).

\footnotetext{
${ }^{6}$ The German rocket scientist Wernher von Braun's technological radical V2 rocket was a crucial last hope for the Nazi regime towards the end of WWII. The story of von Braun is well known and his work on both the Nazi and Cold War American rocket programmes made him a symbol for the continuity of Nazi scientific fantasies into the Cold War (MacDonald, 2008: 617). What is perhaps less known is the fact that the $\mathrm{V}_{2}$ also served as a prototype for the first Soviet Intercontinental Ballistic Missile (ICBM).
} 
This paper has only begun to explore the theoretical and political implications of this rather unusual site. Still pending is a systematic discussion of this bunker in relation to other governmental and non-governmental nuclear shelters as well as nonatomic bunkers. Also missing is a detailed examination of the NATO simulations performed in the bunker as instances of ludic geopolitics (Dittmer, 2013; MacDonald, 2008: 612). Such an investigation would complement peopled studies (Bennett, 2011b; Garrett, 2011) of contemporary bunkers with a more historical narrative of geopolitical scenarios, monotonous daily routines as well as the overflow of alcohol and violence. Thirdly, further work could shed light on the question of enjoyment that is often absent from theories of geo- and biopolitics. Interestingly, it was precisely Marienthal's ludic, deadly and libidinal dimensions that made it an object of fascination and desire in East Berlin. A fourth line of inquiry might attempt to unearth the processes that enabled the site's decommissioning. Such a study would seek to understand how securitised spaces are rendered unexceptional and then abandoned by the sovereign. Indeed, an in depth understanding of the bunker as an (in)secure space might stumble on ways in which it helped to abandon itself. 


\section{Bibliography}

Agamben, G. (1998) Homo Sacer: Sovereign power and bare life (Stanford: Stanford University Press)

Agamben, G. (2005) State of exception (Chicago: University of Chicago Press)

Armitage, J. (2009) Virilio: selected interviews (London: Sage)

Barry, A. (2013). The Translation Zone: Between Actor-Network Theory and International Relations. Millennium: Journal of International Studies 41(3): 413429

Bauamt Bonn der Bundesbaudirektion Berlin (1961) 'An das Bundesministerium des Innern z.Hd. von Hern Oberst a.D. von Boelzig', 21 September 1961, Federal Archives Koblenz, B106/50604

Bauman, Z. (1989) Modernity and the holocaust (Cambridge: Polity)

Beck, J. (2011) 'Concrete ambivalence: Inside the bunker complex' Cultural Politics 7(1): 79-102

Belcher, O. et al. (2008) 'Everywhere and nowhere: The exception and the topological challenge to Geography' Antipode 40(4): 499-503

Bennett, L. (2011a) 'The Bunker: Metaphor, materiality and management' Culture and Organization 17(2): 155-173

Bennett, L. (2011b) 'Bunkerology - a case study in the theory and practice of urban exporation' Environment and Planning D 29: 421-434

Breitman, R. et al. (2005) U.S. intelligence and the Nazis (Cambridge: Cambridge University Press)

Bundesinnenminsterium (1959a) 'Gutachten zur Bestandsaufnahme für Alagen des THW, Dr.-Ing. P. Walter', 15 April 1959, Federal Archives Koblenz, B157/6094

Bundesinnenministerium (1959b) 'Baufachliches Gutachten über die "Anlagen des THW” 15 May 1959, Federal Archives Koblenz, B157/3842

Bundesinnenministerium (1960) 'An den Herrn Bundesminister für Verkehr z.Hd. Herrn MinRat Busse o.V.i.A.' March 1960, Federal Archives Koblenz, B106/5041

Bundesinnenministerium (1961) 'An das Referat IV A 4 im Hause' 4 October 1961, Federal Archives Koblenz, B106/50604

Bundesinnenministerium (1965) 'An das Bauamt Bonn der Bundesbaudirektion' 7 August 1965, Federal Archives Koblenz, B157/6096

Bundesinnenministerium (1966) 'An die Baudirektion Bauleitung Marienthal', 30 December 1966, Federal Archives Koblenz, B157/6095

Bundesinnenministerium (1969) 'Vermerk: Anlagen des THW in Marienthal; hier: Filteranlagen', 21 April 1969; Federal Archives Koblenz, B157/6094

Bundesinnenministerium (1973) 'Lichtbilder vom Bau der Anlage Marienthal', 20 December 1973, Federal Archives Koblenz, B157/6095

Bundesbaudirektion (1968a) 'An den Bundesschatzminister z.Hd. Herrn Ministerialrat Camerer o.V.i.A.' 26 July 1968, Federal Archives Koblenz, B157/6094

Bundesbaudirektion (1968b) 'An das Bundesschatzministerium z.Hd Herrn Min.-Rat 
Siemsen' 29 January 1968, Federal Archives Koblenz, B157/6094

Bundesbaudirektion (1968c) 'Erläuterungsbericht für das Bauvorhaben "Anlagen des THW, 2.Teil, "West”, hier: Einbau einer CO-Warnanlage' Federal Archives Koblenz, B157/6094

Bundesschatzministerium (1967) 'An den Herrn Bundesminister für Verkehr' 21 September 1967, Federal Archives Koblenz, B157/6095

Coaffee, J., O’Hare, P. and Hawkesworth, M. (2009) 'The Visibility of (In)security: The Aesthetics of Planning Urban Defences Against Terrorism' Security Dialogue 40(4-5): 489-511

Dalby, S. (1990) Creating the Second Cold War: The Discourse of Politics (London: Pinter)

Der Spiegel (1984) 'Sieben Eide' 16/84: 66-76

Der Spiegel (1985) 'Armee gegen Streikende' 27/85: 15

Diester, J. (2009) Geheimakte Regierungsbunker: Tagebuch eines Staatsgeheimnisses (Düsseldorf: Verlagsanstalt Handwerk GmbH)

Diester, J. and Karle, M. (2013) Plan B: Bonn, Berlin und ihre Regierungsbunker (Düsseldorf: Verlagsanstalt Handwerk GmbH)

Die Zeit (1966) ‘Der Aufstand der Linken’ 2 December 1968 49: 8

Diken, B. and Lautsen, C. B. (2006) 'The camp' Geografiska Annaler 88B(4): 443-552

Dittmer, J. (2013) 'Geopolitical assemblage and complexity' Progress in Human Geography online first doi:10.1177/0309132513501405

Dittmer, J. (2013) 'Humour at the modern United Nations: the role of laughter in constituting geopolitical assemblages' Geopolitics 18(3): 493-513

Dodds, K. (2003) 'Cold War geopolitics', in J, Agnew, K. Mitchell and G. Toal (eds.) Companion to Political Geography (Malden: Blackwell) 204-218

Duffield, M. (2011) 'Total war as environmental terror: linking liberalism, resilience and the bunker' South Atlantic Quarterly 110(3): 757-769

Edkins, J. (2000) 'Sovereign power, zones of indistinction, and the camp' Alternatives: global, local, political 25(3): 3-25

Elden, S. (2013) 'Secure the volume: Vertical geopolitics and the depth of power' Political Geography 34: 35-51

Farish, M. (2004) 'Another anxious urbanism: simulating defence and disaster in Cold War America', in Graham, S. (ed.) Cities, war, and terrorism: towards an urban geopolitics (Oxford: Blackwell): 93-109

Foucault, M. (1976) Society must be defended: Lectures at the Collège de France, 19751976 (New York: Picador)

Foucault, M. (1978) The History of Sexuality Part I: The Will to Knowledge (London: Penguin)

Fregonese, S. (2012) 'Urban geopolitics 8 years on: Hybrid sovereignties, the everyday and geographies of peace' Geography Compass 6(5): 290-303

Gane, M. (1999) 'Paul Virilio's bunker theorizing' Theory, Culture and Society 16(5/6): $85-102$ 
Garrett, B. L. (2011) 'Shallow excavation, a response to Bunkerology' Environment and Planning $D$,

http://societyandspace.com/material/commentaries/exchanges/bradley-lgarrett-shallow-excavation-a-response-to-bunkerology/ [accessed 5 March 2011]

Gemeindeverwaltung Dernau (1971) 'An die Bundesbaudirektion', 23 July 1971, Federal Archives Koblenz, B157/6094

Giaccaria, P. and Minca, C. (2011) 'Topographies/topologies of the camp: Auschwitz as a spatial threshold' Political Geography 30: 3-12

Graham, S. (2004) 'Vertical Geopolitics: Baghdad and after' Antipode 36(1): 12-23

Gregory, D. (2006) 'The black flag: Guantanamo bay and the space of exception' Geografiska Annaler 88B(4): 405-427

Gregory, D. (2007) 'Vanishing points' in D. Gregory and A. Pred (eds.) Violent geographies: Fear terror and political violence (London: Routledge): 205-236

Gückelhorn, W. (2002) Lager Rebstock (Aachen: Helios)

Haushofer, K. (1928) 'Rheinische Geopolitik', in K. Haushofer (ed.) Der Rhein: Sein Lebensraum/sein Schicksal [1. Band/Erdraum und Erdkräfte] (Berlin: Kurt Vowinckel Verlag): 1-16

Hirst, P. (2005) Space and power: politics, war and architecture (Cambridge: Polity)

Hochtief (2014) 'My company, our history', at http://www.hochtief.com/hochtief en/74.jhtml;jsessionid=DCF768CD241FF1B4E 6CACD4FEF9BD48D [accessed 11 February 2014]

Janta, L. Rieck, H. and Riemenschneider, M. (1989) Kreis Ahrweiler unter dem Hakenkreuz (Bad Neuenahr-Ahrweiler: Landkreis Ahrweiler)

Jungbluth, U. (2000) Wunderwaffen im KZ "Rebstock" (Briedel: Rhein-Mosel Verlag)

Kjellén, R. (1920) Grundriss zum einem System der Politik (Leipzig: S. Hirzel Verlag)

Laclau, E. (2007) 'Bare life or social indeterminacy', in M. Calarco and S. DeCaroli (eds.) Giorgio Agamben: Sovereignty and life (Stanford: Stanford University Press): 11-22

Luke, T. \& Ó Tuathail, G. (200o) 'Thinking geopolitical space: The spatiality of war, speed and vision in the work of Paul Virilio' in M. Crang (ed.) Thinking space (London: Routledge)

MacDonald, F. (2006a) 'The last outpost of empire: Rockall and the Cold War' Journal of Historical Geography 32: 627-647

MacDonald, F. (2006b) 'Geopolitics and 'the Vision Thing': regarding Britain and America's first nuclear missile' Transactions of the Institute of British Geographers 31: 53-71

MacDonald, F. (2008) 'Space and the atom: On the popular geopolitics of Cold War rocketry' Geopolitics 13(4): 611-634

Matless, D. Oldfield, J. and Swain, A. (2008) 'Geographically touring the eastern bloc: British Geography, travel cultures and the Cold War' Transactions of the Institute of British Geographers 33(3): 354-375

Mazower, M. (2008) 'Foucault, Agamben: Theory and the Nazis' Boundary 2 35(1): 2334 
Minca, C. (2005) 'The return of the camp' Progress in Human Geography 29(4): 405-412

Minca, C. (2006) 'Giorigio Agamben and the new biopolitical nomos' Geografiska Annaler 88B(4): 387-403

Ministerium für Staatssicherheit (1966) 'Sonderbericht Nr. 2/66 der Verwaltung Aufklärung des MfNV', 1 November 1966, The Federal Commissioner for the Stasi Archives, MfS ZAIG Nr. 6630

Ó Tuathail, G. \& Agnew, J. (1992) 'Geopolitics and discourse: Practical geopolitical reasoning in American foreign policy' Political Geography 11(2): 190-204

Ó Tuathail, G. (1996) Critical geopolitics: The politics of writing global space (Minneapolis: University of Minnesota Press)

Pohl, M. (1999) Philipp Holzmann: Geschichte eines Bauunternehmens 1849-1999 (München: C.H. Beck)

Preute, M. (1984) Vom Bunker der Bundesregierung (Köln: Edition Nachtraben)

Ramadan, A. (2009) 'Destroying Nahr el-Bared: Sovreignty and urbicide in the space of exception’ Political Geography 28: 153-163

Ramadan, A. (2013) 'Spatialising the refugee camp' Transactions of the Institute of British Geographers 38: 65-77

Ratzel, F. (1901) 'Der Lebensraum: eine biogeographische Studie', in K. Bücher et al. (eds.) Festgaben für Albert Schäffle zur siebenzigen Wiederkehr seines Geburtstages (Tübingen: Lapp)

Rutherford, P. and Rutherford, S. (2013) 'The confusions and exuberances of biopolitics' Geography Compass 7(6): 412-422

Sharp J (2000) Condensing the Cold War: Reader's Digest and American Identity (Minneapolis, MN: University of Minnesota Press)

Shaw, M. (2008) 'New Wars of the City: Relationships of "Urbicide" and "Genocide", in S. Graham (ed.) Cities, War, and Terrorism: Towards an Urban Geopolitics (Blackwell Publishing: Malden, MA): 141-153

Speer, A. (1970) Inside the Third Reich (London: Phoenix)

Vanderbilt, T (2002) Survival city: adventures among the ruins of atomic America (New York: Princeton Architectural Press)

Van Houtum, H. (2010) 'Human blacklisting: the global apartheid of the EU's external border regime' Environment and Planning D 28(6): 957-076

Vaughan Williams, N. (2009) 'The generalised bio-political border? Re-conceptualising the limits of sovereign power' Review of International Studies 35(4): 729-749

Virilio, P. (1975) Bunker archaeology (NY: Princeton Architectural Press)

Virilio, P. and Lotringer, S. (1983) Pure War (New York: Semiotexte)

Weizman, E. (2007) Hollow land: Israel's architecture of occupation (London: Verso)

Woodward, R. (2014) 'Military landscapes: agendas and approaches for future research' Progress in Human Geography 38(1): 40-61 